\title{
恝.
}

\section{アルミニウムおよびその合金溶接部の諸性質におよぼす 含有水素ガスについで}

\author{
安藤 良夫** 藤 村理 人***
}

\author{
Behavior of Hydrogen Gas in Welds of Aluminium \\ and Its Alloys*
}

By Yoshio Ando** and Tadato Fujimura***

1. 序論

一般に金属内に含有されるガスが金属の諸性質に大き な影響を与えることが知られている1-4)。

その場合，影響を与える主なガスの種類は水素，酸 素，窒素である，アルミニウム㧍よびその合金において もこれらのガスの影響は例外ではないが，アルミニウム と窒素の間では AlN またはアルミニウムと酸素の間で は $\mathrm{Al}_{2} \mathrm{O}_{3}$ という比較的安定な化合物つくって金属中に または金属表面化析出することになるので，窒素および 酸素の影響はてれら化合物の影響におきかえられること になる、ところが，一方，アルミニウム合金中に含有さ れる水素はどういう形で存在するのかいまだ十分明かで はないが，アルミニウムの含有ガスを分析すると全ガス 量の $80 \%$ 以上が水素であるてとが明らかにされている. すなわち，アルミニウム中には水菜が単体として含有さ れ，直接的䎲諸性質に影響するととがわかる。しかしな がら，後に述べごとく，アルミニウムと水素との間に は溶解吸收というような簡単な現象で片づけられないい くつかの問題点を有している．ともあれ，アルミニウム の諸性質化直接影響する含有ガスは水素であると限定し て考えてさしつかえないと思われる，そのため，ててで はアルミニウムおよびその合金溶接部の諸性質におよぼ す含有ガスを水素に限ってその影響を論究することにす る.

アルミニウム抢よびその合金の溶接部の諸性質に含有 された水素がどのように影響するかは，いくつかの文献

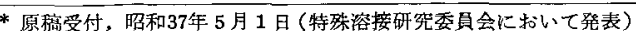

** 正員, 東京大学生産技術研究所 Member, Instituse of Industrial Science, University of Tokyo

*** 正具, 日本原子力研究所東海研究所 Member, Tokai Laboratory, Japan Atomic Energy Research Institute
で知られているが5-10)，第 1 亿，気孔を生じ外見的にス エイング，ブリスターなどを生ずること，第 2 には機械 的性質の劣化を生ずることである。また最近では原子炉 構造などの高品質構造においてリーク・タイトが要求さ れるがてれに対する含有ガスの影響はいうまでもなく明 らかである。

アルミニウム合金溶接部に拉ける水素の影響は，1） 気孔となった水素の影響と 2）固溶した水菜の影響とに わけるととができる，前者は主としてマク口的な影響と なってあらわれ，後者注としてミク口的な影響となっ てあらわれる。

以下著者らはこれらの諸影響を次のいくつかの論点に 分けて述べるととにする。

1）機械的性質と水素の影響

2）溶接条件上水素の影響

3）溶接心線の処理と水素の影響

4) 溶接部に含有する水素の理諭

\section{2. 含有水素の機械的性質におよぼ す影響}

Daley, M.D. は Al-Mg 合金の溶接部の気孔が機械的 性質におよばす影響を研究した7゙。乙れはミサイルの開 発研究において，燃料庫，ボディ，エンジンなどに使用 する $\mathrm{Al}-\mathrm{Mg}$ 合金について検討したものである.

図一 1 は母材（規格 5086-H 44, Si : 0.40\%, Fe : 0.50 $\%, \mathrm{Cu}: 0.10 \%, \mathrm{Mn}: 0.20 \sim 0.7 \%, \mathrm{Mg}: 3.5 \sim 4.5 \%, \mathrm{Cu}$ : $0.05 \sim 0.25 \%, \mathrm{Zn}: 0.25 \%$ ） 老心線（規格 5356, Si : $0.50 \%, \mathrm{Cu}: 0.10 \%, \mathrm{Mn}: 0.05 \sim 0.20 \%, \mathrm{Mg}: 4.5 \sim 5.6 \%$, $\mathrm{Cr}: 0.05 \sim 0.20 \%, \mathrm{Zn}: 0.10 \%)$ で Tig 溶接した溶接部 について，溶接部気孔の機械的性質への影響を示したも 


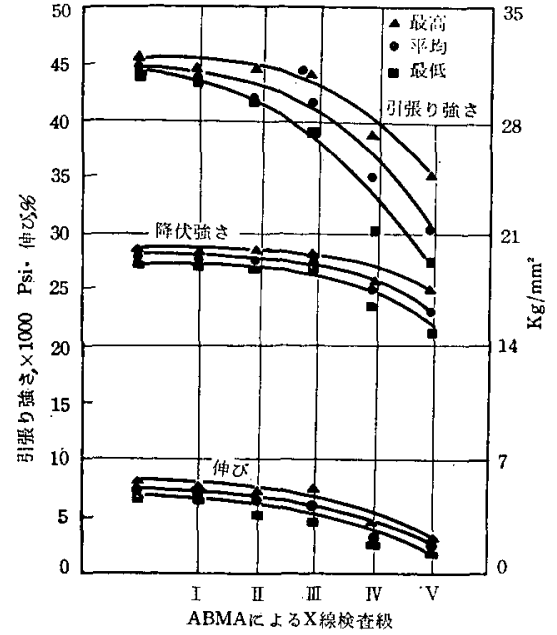

図一1 $\mathrm{A} 1-\mathrm{Mg}$ 合金溶接部の気孔 (ABMA) 上強度の関係

のである．横軸に気孔のX線検査級をとっているが，こ の級は ABAM (Army Ballistic Missile Agency) のX 線検查規格である。

日本溶接協会ではアルミニウム合金溶接部の検査規準 をつくるため，溶接部の欠陷と機械的諸性質抢よび腐食 性におよぼす影響を求める研究を行なった11)。同研究に 用いられた Al-Mg 合金は母材 (ANP-0, Cu : 0.10\%>, $\mathrm{Si}: 0.40 \%>, \mathrm{Fe}: 0.40 \%>, \mathrm{Mn}: 1.0 \%>, \mathrm{Mg}: 3.0 \sim$ $4.7 \%, \mathrm{Cr}: 0.50 \%>, \mathrm{Zn}: 0.10 \%>, \mathrm{Ti}: 0.27 \%>$ ) を心 線 (ANW) で溶接したものである.

図一 2 および図一 3 は引張り試験により気孔之強度の 関係を求めたあのである. 継手效率は同形の母材試験片 の平均引張り強さ $\left(29.9 \mathrm{~kg} / \mathrm{mm}^{2}\right)$ を $100 \%$ として継手の

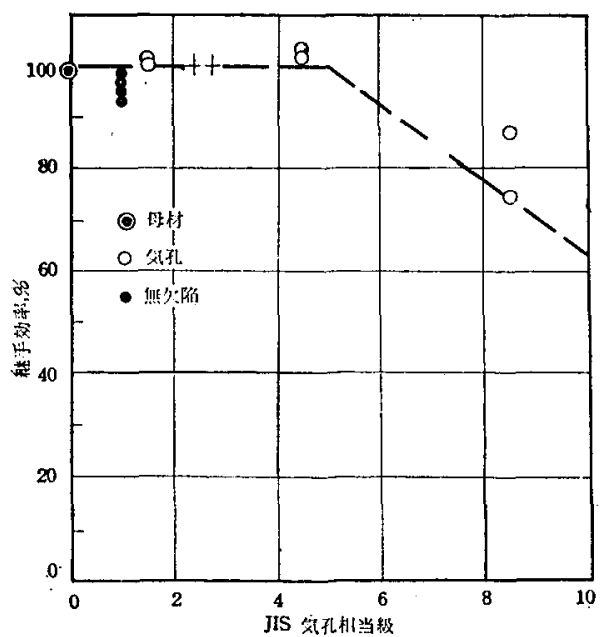

図一2 溶接継手の引張り強さと気孔の関係 (余盛 りあり)
強度を示したものである. 余盛りのある場合は JIS 4〜5 級でも笑合せ継手の継手效率は 100\%であるが，7級で は溶接部で破断している．余盛りを削除したむのは，気 孔が $1 \sim 2,4 \sim 5,7 \sim 10$ 級と墨くなり欠宿が大きく なるにしたがって継手效率は低下している。

著者らは同じ材料を型曲げ陚験によって溶接部気孔と 継手強度の関係を求めた ${ }^{12}$. 表一1はにの試験結果を示 す. この試験の結果, A-4 型冶具で試験したとき，裹

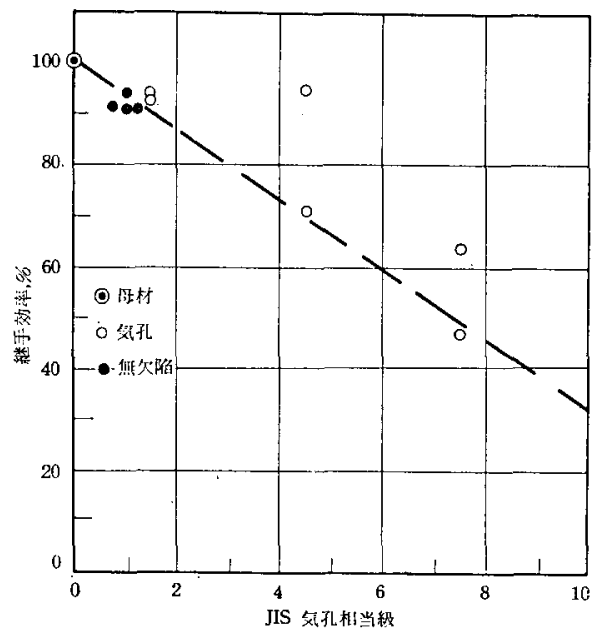

図一 3 溶接継の引張り強さと気孔の関係 (余盛り削除)

表一 $1 \quad \mathrm{Al}-\mathrm{Mg}$ 合金溶接部の気孔と型曲 げ試 験結果の関係

\begin{tabular}{|c|c|c|c|c|}
\hline \multirow{2}{*}{ 試験片番号 } & \multicolumn{2}{|c|}{ 犁曲げ陚呀 } & \multirow{2}{*}{ 気孔率\% } & \multirow{2}{*}{$\begin{array}{c}\text { X線検查 } \\
\text { JIS 級 }\end{array}$} \\
\hline & A-2 型冶具 & A-4 型冶具 & & \\
\hline$I-1$ & F $O$ & - & 一 & $0^{*}$ \\
\hline $1-2$ & $R O$ & - & - & $0^{*}$ \\
\hline $1-3$ & $\mathrm{~F} O$ & - & - & $0^{*}$ \\
\hline $1-4$ & $\mathrm{R} O$ & - & - & $0^{*}$ \\
\hline $1-5$ & - & F $O$ & - & $0^{*}$ \\
\hline $1-6$ & - & R $O$ & - & $0^{*}$ \\
\hline$\llbracket-1$ & - & F $O$ & 0.35 & $0^{*}$ \\
\hline$\rrbracket-2$ & 一 & F $O$ & 0.41 & $0^{*}$ \\
\hline $1-7$ & $\mathrm{~F} \times$ & 一 & - & $\mathbf{I}$ \\
\hline$I-8$ & $\mathbf{R} \times$ & - & - & 1 \\
\hline$I-9$ & - & F $O$ & - & 1 \\
\hline$I-10$ & - & $\mathrm{R} O$ & - & 1 \\
\hline $\mathbb{I}-3$ & - & F $O$ & - & 1 \\
\hline$I I-4$ & - & F $O$ & - & 1 \\
\hline$I I-5$ & - & F $O$ & 0.42 & 2 \\
\hline$I-6$ & - & $F \quad \times$ & 一 & 3 \\
\hline $1-11$ & - & $\mathbf{F} \times$ & - & 4 \\
\hline $\mid-12$ & - & R $O$ & - & 4 \\
\hline$I-7$ & - & $F \times$ & - & 4 \\
\hline $\mathbb{1}-8$ & - & $F \quad x$ & 0.63 & 5 \\
\hline$J-13$ & - & $F \quad x$ & - & 7 \\
\hline $1-14$ & - & $R O$ & - & 7 \\
\hline
\end{tabular}


曲げ試験は全部合格したが，表曲げ試験ではX線検査 JIS 2 級までは合格，それ以下は不合格という結果とな った，表曲げ試験と裹曲げ試験の差違は気孔が溶接部表 側に集中する傾向によると思われる．また JIS 3 級以 下の不合格の要因については 5 で考察する。

\section{3 . 溶接条件と溶接部の含有水素ガス}

アルミニウム合金溶接部の気孔は溶接条件によって左 右されることはいうまで寻ない，しかし，一椹に溶接条 件といってむ，その因子は多程多様である，これらの因 子を整理すると次のごとくなる.

A) 溶接施工条件

溶接電流，溶接電压，アルゴン流昌などの溶接施工 条件.

B) 溶接時の熱的条件.

バッキングの状態，溶接速度などにより，溶接入憼 および熱伝達の状態が異る、すなわち，冷却速度，溶 融池の温度，溶融池の龊固時間などの因子

C) 溶接施工雾囲気.

湿度，気温なよ゙溶接施工の場所の影響

これらの3 条件は独立的な因子でなく，溶接施工にあ たっては常に複合してあらわれる.そのため，溶接部気 孔に最屯強い影響を与える因子を捉えることはなかなか 困難である.アルミニウム合金材料溶接において無気孔 の健全な溶着部を得るととの图難さむとの辺にあるむの と考えられる。

著者らは Al-Mg 合金（52S）を心線（54 S) で Tig

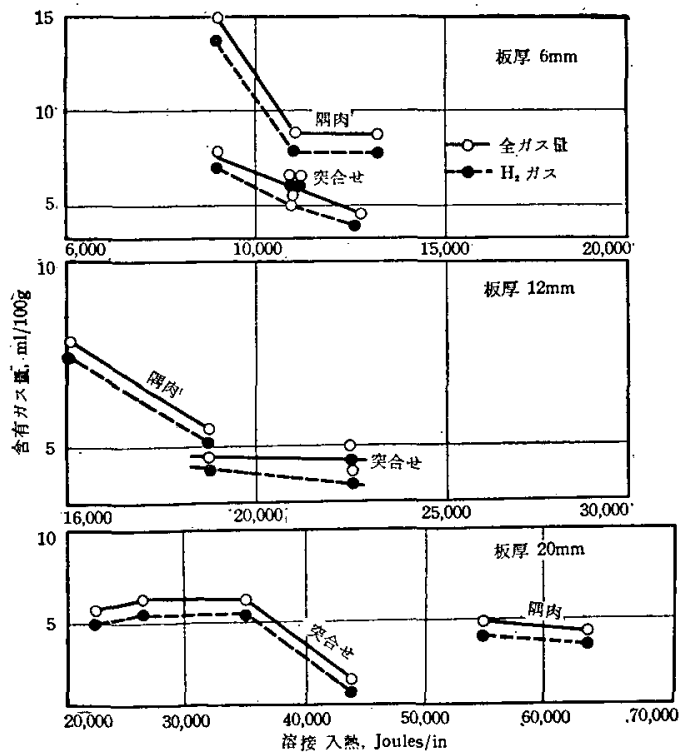

図一 $4 \mathrm{Al}-\mathrm{Mg}$ 合金溶接部の含有ガス量と溶接入 熱の関係
法に上り溶接した場合の浴接条件と溶接部の含有水菜の 影響を検討した9).

図一 4 は溶接時の溶接入熱が溶接部の含有ガス量*に およぼす影響を示すものである。一般に溶接入熱が大き い亡き，含有水菜量は少なくなる傾后にある.すなわ ち，溶接速度が早いとさは含有水素量は多くなる傾问が ある。また Tig 溶接法より Mig. 溶接法の方が気孔も 多くあらわれる、図一5は同じ溶接部における溶接入熱 とX線による気孔数との関係を示すむのであるが図 -4 に示す結果と同様な傾向を示している.

図一6は溶接部の予熱が含有水菜量におよばす影響
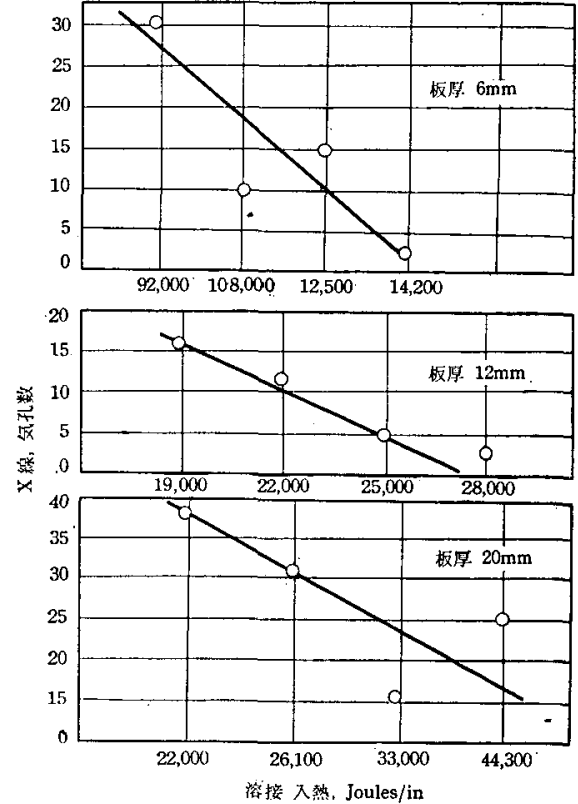

図一 $5 \mathrm{Al}-\mathrm{Mg}$ 合金溶接部のX線気孔数と溶 接入熱の関係

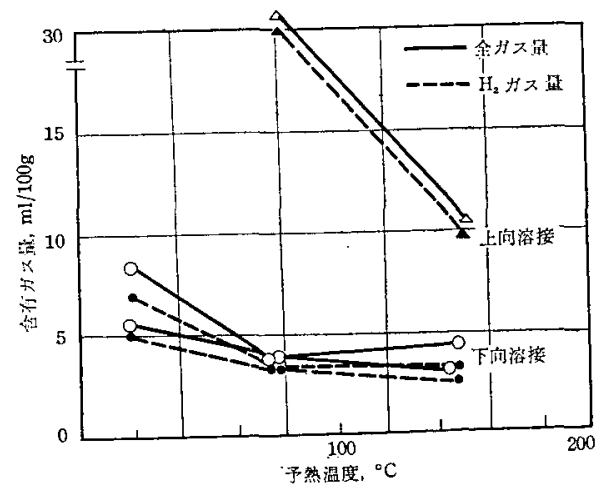

図一 $6 \quad \mathrm{Al}-\mathrm{Mg}$ 合金溶接部の含有水素量之予 熱温度の関係

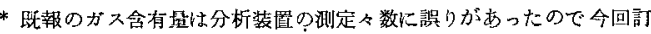
正した。 
を示したものである.予熱によって含有水素量の低下が あらわれている．また上向き溶接ではきわめて多富の水 素を含有することがわかる，板厚についていえば板厚の 大きい程水素含有量が少ない傾向がある.

鈴木，村㖽氏は附食アルミニウム合金 (ANP) を Mig によって溶接した場合の溶接条件と溶接部気孔の関係を 求めている(13). 図一7，8，9はその実験結果を示す. その結果を要約すると次のでとくである.

1）アークの安定度（アーク電圧）と気孔の関係 一般に，アーク電圧が低い程気孔が少ない，150 A 程 度の低電流でしか李過大電圧 $(28 \mathrm{~V})$ の場合には気孔の 発生が多い。

アーク電王の影響はアーク電流の大きい場合（例えば $250 \mathrm{~A})$ それほどいちじるしくあらわれない．その理由 は高電流を用いると気孔が減少する傾何があるためであ る.

2) 溶接入熱（溶接電流, 溶接速度）上気孔の関係 溶接電流の增加，溶接速度の減少飞と屯ない溶接入熱 は增加して, 溶融池の溶融時間が長くなりガスの放出が 容易になる。

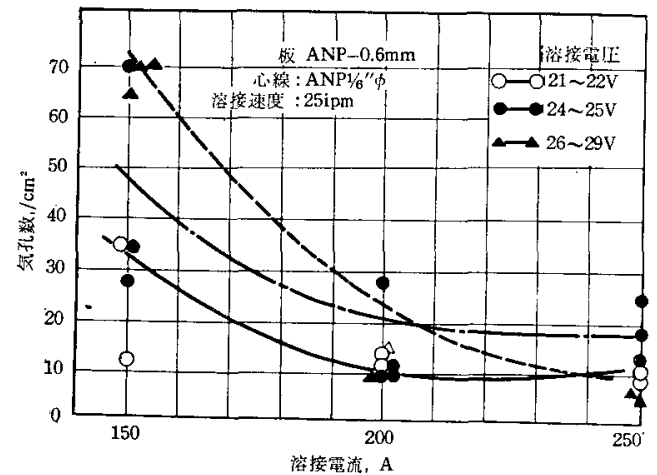

図一 7 溶接部気孔之溶接電流の関係

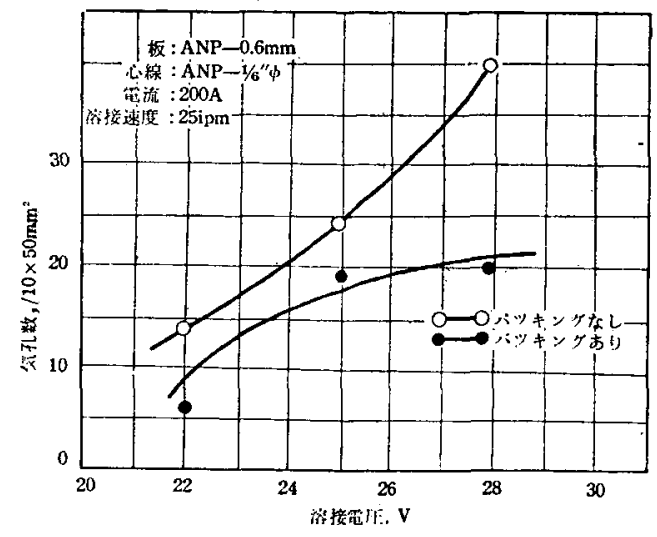

図-8 溶接部気孔と溶接電圧の関係

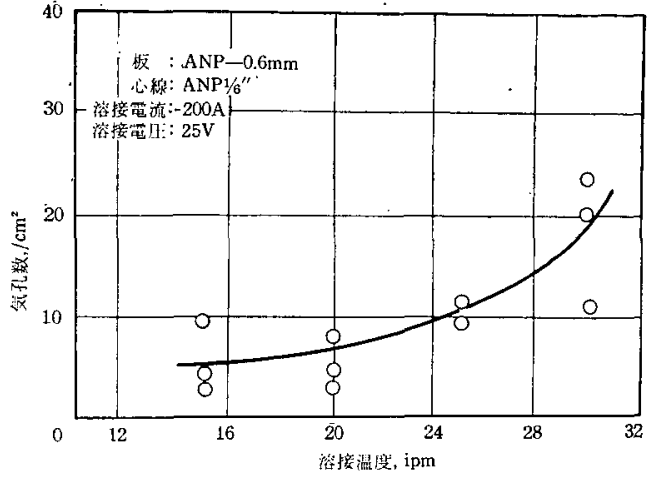

図-9 溶接部気孔と溶接速度の関係

溶接速度が $25 \mathrm{ipm}$ 以下では気孔の数は減少しており， アーク電流 $15 \mathrm{ipm}$ 以下になるとX線気孔は全く見乃れ なくなった。

昭和 32 年:日本溶接協会原子力研究委員会は“原子炉 およびその附属装置に必要なアルミニウムおよびステン レス鋼の溶接施工ならびに検査に関する試験研究”を実 施したが，そのなかで，溶接部気孔の研究を各研究機関 と各社が実施し，山口氏*驾まとめた報告がある14).

それによると，工業純アルミニウム $(2 \mathrm{~S})$ とアルミ ニウム合金 $(52 \mathrm{~S}$ ，心線は $54 \mathrm{~S})$ を用いて溶接した場合 の溶接部気孔の発生について明らかにされている. 図一 10亿示されるごとく, 溶接入熱, 溶接電流と気孔の関係 は Mig. 法の場合, 適正電流をはずれたときは気孔の発 生は多く，溶接入熱が大きいはど気孔の発生は少なくな るが，同一入熱の場合でも電流の大小さになり，溶接部 気孔の発生は大きく影響される.

また冷却速度亡断面検查による溶接部気孔の関係につ いては，図一11亿示されるごとくで，その影響は相当大 きいととがわかる。

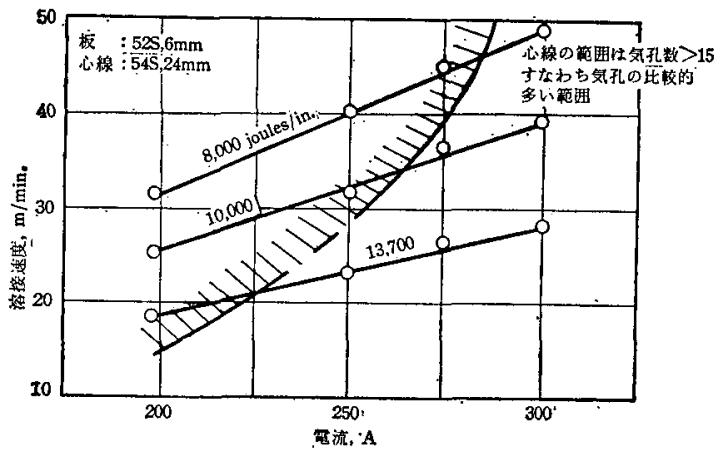

図一10 溶接入熱と溶接部気孔の関係

* 茨城大学工学部 


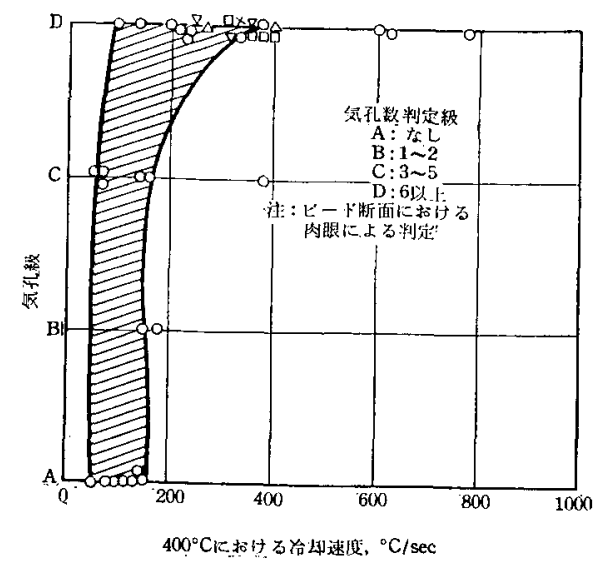

図一11 溶接部の冷却速度と溶接部気孔の関係

\section{4. 溶接心線の処理と含有水素ガス の関係}

溶接部の含有水菜量は，板自体の含有水素量求よび溶 接心線の念有水菜量により大きな影響を与られる。乙

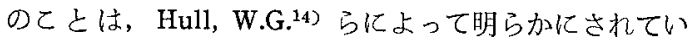
る.

溶接心線より溶接部に入る水素源については次のご上 くわけるとよができる.

1）溶接心線内に含有するガス

2）溶接心線の表面にできた腐食生成物の結晶水が溶 接に際して分解するもの

3）溶接心線の表面にできた酸化皮膜に吸着している

表一2 アルミニウム $(2 S)$ 溶接心線の前処理と弇 有ガス量の関係

\begin{tabular}{|c|c|c|c|c|c|}
\hline 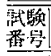 & 心線の処理 & 処理目的 & 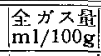 & $\begin{array}{c}\text { 水䨛量 } \\
\mathrm{H}_{2} \mathrm{ml} / 100 \mathrm{~g}\end{array}$ & 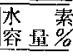 \\
\hline 1 & 線引のま & 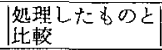 & 2.8 & 2.1 & 74.9 \\
\hline 2 & $\mid$ & 多量の水分の附 & 8.7 & 6.9 & 79.3 \\
\hline 3 & 表面を機㭜的に削除 & $\mid$ & 1.6 & 1.3 & 81.3 \\
\hline 4 & \multirow{3}{*}{ 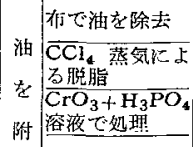 } & 䌪学な処理 & 2.9 & 2.4 & 82.9 \\
\hline 5 & & 蒸気処理 & 1.8 & 1.1 & 61.1 \\
\hline 6 & & & 1.8 & 1.3 & 72.2 \\
\hline 7 & 着 $\mathrm{C}_{6} \mathrm{H}_{6}$ て脱脂 & 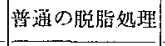 & 2.1 & 1.3 & 61.9 \\
\hline 8 & 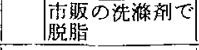 & & 2.7 & 1.3 & 48.2 \\
\hline 9 & $\begin{array}{l}15 \% \mathrm{NaOH} \text { 溶液で } \\
\text { 矧甠: }\end{array}$ & 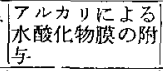 & 3.9 & 3.0 & 76.9 \\
\hline 10 & $\begin{array}{l}15 \% \mathrm{NaOH} \text { 溶 } \\
2 \text { 分間㐐理後 } \\
15 \% \mathrm{HNO} \\
\text { 中和 }\end{array}$ & 普処の蒜面処理 & 1.0 & 0.7 & 70.0 \\
\hline 11 & $\begin{array}{l}10 \% \mathrm{HNO}_{3}+2.5 \% \\
\mathrm{HF} \text { 溶掖で処理 }\end{array}$ & 酸化皮膜の除去 & 1.5 & 1.1 & 73.4 \\
\hline 12 & 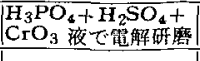 & 最眼の表面处理 & 1.0 & 0.7 & 70.0 \\
\hline 13 & 外园の心線 & 比校のため & 2.3 & 1.6 & 69.5 \\
\hline
\end{tabular}
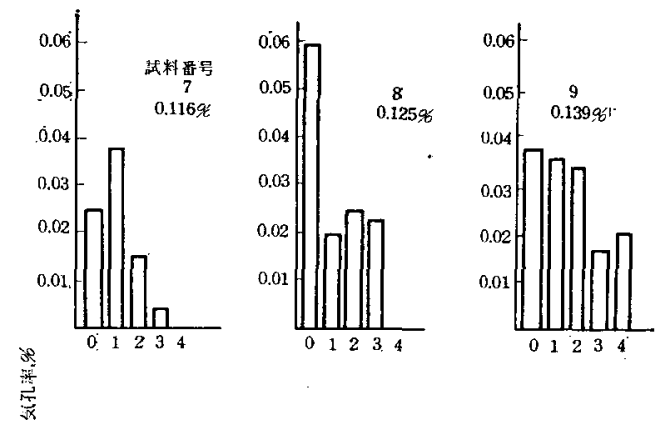

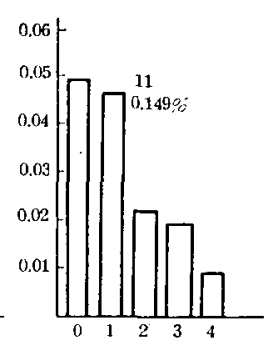

匃孔得㭧排数

図一12 Al (2S) 溶按部の心線の処理と気孔 率の関係

ガス.

これらのガスが溶接部の會有ガスに大きな影響を与 えるととは鈴木氏らと著者らの笑験でも明らかであ る ${ }^{1213)}$. すなわち，工業用純了ルミウム $(2 \mathrm{~S})$ の溶接 心線を各種の処理をしてガス分析をしてみると表一 2 に 示すごとくなる.との表において明らかなどとく，処理 の悪い溶接心線で溶接した溶接部は図一12に示すように 溶着部の気孔率が多くなる。

わが国では溶接心線の製造工程の管理や，溶接前処理 に比較的無関心で劣るが，溶接心線の処理および取扱い については細心の注意が必要であるととを喚起しなけれ ばならない，軽金属協会船舶用軽金属委員会では Mig. 用溶接心楾について心線の表面処理の影響を見在検討し ているがその結果は注目すべきであろう。

\section{5. 溶接部に含有される水素ガスの 理論}

最近，ようやく金属内に含有されるガスの状態につい て，その機構が明らかれされ，理諭的な説明が行なわれ つつある。一般に金属に念有されるガスの状態は吸着 (adsorption) 上吸收または溶解（absorption or dissolution）の 2 つに大別される.

吸着はさらに物理的吸着 (physical adsorption) と化 学的吸着 (chemical adsorption, chemisorption) また は活性化吸着 (activated adsorption) に水けて考えら 
れている。

物理的级着亡は金属表面に1分子層の厚さで，分子間 力（Van der Waals 力）により金属表面原字とガス分 子が絬合する状態である，物理的吸着による吸着ガスは 温度し压力に關して完全に可逆的な吸着を示す.

また，化学的吸著の場合はガス之金属の間に，ある程 の化学的結合をもち，吸着するガスの状態をさすむので ある，乙の場合，吸着の状態は非可逆的であり，吸着の 力も溞く，かつ吸着されるガスの量も物理的吸着に比べ る亡はるかに多いのが特徽である。

このように吸着を考えるとき，夷際に金属の諸性質に 影響をおよぼすガスは化学的吸着により吸峟されたガス によると考えるのが正しい.

しかしながら，化学的吸着によるガスはそのままの状 態で金属の渚性質に影罯するのではなくて，これらのガ スは拡散により，金属内部に吸取または固溶されること によってはじめて金属内部に含有されるガスとなる、す なわち、アルミニウム合金に含有された水素の影響とは このような過程を経て固溶，吸收された水素の影響しい うことになる，ここで溶接部に含有される水素について 考えてみると，1つは母材および心線自体に固溶する水 素である．これはひとまず拈くことにして，溶接施工に 際して外部から入る水素を考えてみると，大気中に含ま 机る水素䕗は少ない儿，加水菜分子が解離して金属中 に入るという考え方は水素分子の解離压扰よび解離温度 が忽いので水素が単独で原子状で固溶するということは

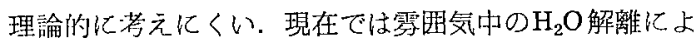
ってできる水榇原子がアルミニウムに溶解する上考える のが定説となっている.すすねち。

$$
2 \mathrm{Al}+3 \mathrm{H}_{2} \mathrm{O} \rightarrow \mathrm{Al}_{2} \mathrm{O}_{3}+6 \mathrm{H}
$$

しかしながら，先に述べたじとく溶接時において溶着 金属に溶解するまでの過程を考えることが必要である。

霓囲気中の $\mathrm{H}_{2} \mathrm{O}$ は舟材まはた心線表面に化学的吸礿 される，この場合，テルミニウム母材の表面は酸化殿膜 で得われているので，化学的吸着はアルミニウムと $\mathrm{H}_{2} \mathrm{O}$ の吸着と考えると同時に，アルミニウム酸化物と $\mathrm{H}_{2} \mathrm{O}$ の吸着を考えることが必要である，との場合，酸化物が

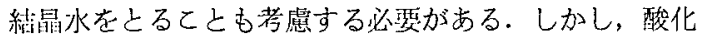
皮膜をつくる要因む雾囲気中の $\mathrm{H}_{2} \mathrm{O}$ にあるこしは(1) 式によって明らかである。てのようにして吸着した $\mathrm{H}_{2} \mathrm{O}$ は溶接時の熱とアークによるイオン化傾向によりアルミ ニウム中に容易に溶解する。なおアルミニウム印にマグ. ネシウムがあるとき，

$$
\mathrm{Mg}+\mathrm{H}_{2} \mathrm{O} \rightarrow \mathrm{HgO}+2 \mathrm{H}
$$

の反応により， $\mathrm{H}_{2} \mathrm{O}$ の解離は促進される. マグネシウ 么は溶接中倍接表面に拡散する傾问があり，かつマグ
ネシウムはアルミニウムより活性であるから，[H]の できる量が多い，これが Al-Mg 合金で含有水䇣がス量 の多い第 1 の要因と考えられる. 溶接時アルミニウム表 面にできた[H]は溶融池中に搪散するが，その拡散述庭 は純アルミニウムにおけるより，不純なアルミニウム， さらにアルミニウム合金の㙅合ば大きいようである.

このようにして溶解した $[\mathrm{H}]$ は，どのような型で金 属中に存在するかについて 2 通りが考えられている.す なおち，1) endothermic な固溶と 2) exothermic な固 溶である゙4).

endothermic に固溶する水素は，金属格子内に浸入型 として固溶寸る。この型に固溶する $[\mathrm{H}]$ はエネル゙ー を吸収することにより安究化する傾向存するから，温 度が增加するとともに金属内における溶解星は增版す る. この種の型に属する金属は $\mathrm{Fe}, \mathrm{Cu}, \mathrm{Ni}, \mathrm{Co}, \mathrm{Cr}, \mathrm{Mo}$, $\mathrm{Ag}, \mathrm{Pt}$ がある.

exothermic に固溶する水素は金属との閒に置換型で 圆溶し，低いエネルギー状態で安定化している．湿度が 上㫧すると，安定度がくずれ，ガスを放出する傾向を有 する，乙の種の型に属する金属は，Ti， V, W, Ce, Zr, $\mathrm{Ta}, \mathrm{Nb}, \mathrm{Pd}$ な゙がある。これらの金属は前者に比べる とはるかに多量の水素を溶解する。

表一 3 は endothermic な固溶をする金属の水素の溶 解度を示し、表一4は exothermic な固溶をする金属の 水素の溶解度を示す.

また図一13は代表的な金属の溶解度明線を示す。ジル コニウムは exothermic な固溶を示し，高温で溶解度は

表一3 Endothermic な固溶をする金属に刘する 水素の溶解度

\begin{tabular}{|c|c|c|c|c|c|c|c|c|}
\hline \multirow{2}{*}{${ }^{\circ}{ }^{\circ} \mathrm{C}$} & \multicolumn{8}{|c|}{ 金屈 の 利 類 } \\
\hline & $\mathrm{Ni}$ & $\mathrm{Fe}$ & Co & $\mathrm{Cr}$ & $\mathrm{Cu}$ & $\mathrm{Ag}$ & Mo & $\mathrm{Pt}$ \\
\hline 200 & 1.7 & - & - & - & - & - & 一 & - \\
\hline 300 & 2.35 & 0.16 & - & - & $\cdots$ & - & - & - \\
\hline 400 & 3.15 & 0.35 & $\rightarrow$ & $\cdots$ & 0.06 & 0.055 & 0.165 & 0.065 \\
\hline 500 & 4.10 & 0.75 & - & - & 0.16 & 0.110 & 0.175 & 一 \\
\hline 600 & 5.25 & 1.20 & 0.89 & 0.5 & 0.30 & 0.176 & 0.185 & 0.075 \\
\hline 700 & 0.50 & 1.85 & 1,22 & - & 0.49 & 0.232 & 0.21 & - \\
\hline 800 & 7.75 & 2.45 & 1.85 & 1.0 & 0.72 & 0.334 & 0.25 & 0.095 \\
\hline 900 & 9.10 & $\begin{array}{l}3.0(\alpha) \\
4.7(\gamma)\end{array}$ & 2.52 & 2.0 & 1.08 & 0.427 & 0.29 & 0.135 \\
\hline 1,000 & 9.80 & 5.50 & 3.21 & 3.0 & 1.58 & 一 & 0.50 & 0.20 \\
\hline 1,100 & 12.15 & 7.00 & 4.33 & 4.2 & $6.3^{*}$ & - & 0.62 & 0.35 \\
\hline 1,200 & 14.25 & 8.25 & 5.44 & - & 8.1 & - & - & 0.52 \\
\hline 1,300 & 14.7 & 10.1 & - & - & 10.0 & - & $\overline{.}$ & 0.77 \\
\hline 1,400 & 16.2 & $\begin{array}{l}10.5(\gamma) \\
10.1(\sigma)\end{array}$ & - & - & 11.8 & - & - & 1.15 \\
\hline 1,500 & $41.6^{*}$ & - & - & - & 13.6 & - & - & - \\
\hline 1,535 & - & $\begin{array}{l}14(\delta) \\
25^{*}\end{array}$ & - & - & - & - & - & - \\
\hline 1,600 & 43.1 & 28.0 & - & - & - & - & - & 一 \\
\hline 1,650 & - & 31.0 & - & - & - & 一 & - & - \\
\hline
\end{tabular}
$\mathrm{ml} / 100 \mathrm{~g}$

* liquid metal 
表一4 Exothemic な固溶をする金属に対する 水害の溶解度 $\mathrm{ml} / 100 \mathrm{~g}$

\begin{tabular}{|c|c|c|c|c|c|c|c|c|c|}
\hline \multirow{2}{*}{ 温 ${ }^{\circ} \mathrm{C}$} & \multicolumn{9}{|c|}{ 金儌の種類 } \\
\hline & $\mathbf{T} \mathbf{i}$ & V & $\mathrm{Zr}_{\mathrm{r}}$ & $\mathrm{Nb}$ & $\mathrm{La}$ & $\mathrm{Ce}$ & $\mathrm{Ta}$ & $T_{h}$ & $\mathrm{Pd}$ \\
\hline 20 & 40,740 & 15,000 & $23,550 \mid$ & 5,500 & 22,300 & 21,500 & 4,600 & 14,800 & 6,000 \\
\hline 300 & - & 6,500 & - & 4,440 & 19,200 & 18,400 & 3,300 & - & 330 \\
\hline 400 & 38,770 & 3,800 & - & 3,680 & 18,200 & 17,600 & 2,500 & - & 230 \\
\hline 500 & 36,600 & 1,900 & - & 2,270 & 17,200 & 16,800 & 1,400 & - & 190 \\
\hline 600 & 33,470 & 1,000 & $18,400 \mid$ & 988 & 16,300 & 16,000 & 700 & 9,100 & 180 \\
\hline 700 & 18,390 & 640 & $|17,600|$ & 511 & 15,300 & 15,200 & 420 & 8,800 & 170 \\
\hline 800 & 14,090 & 440 & $16,500 \mid$ & 330 & 14,300 & 14,500 & 250 & 8,100 & 162 \\
\hline 900 & 9,820 & 320 & $|13,800|$ & 217 & 13,400 & 13,800 & 180 & 7,700 & 157 \\
\hline 1,000 & 6,610 & 250 & 7,800 & 163 & 12,300 & 13,000 & 140 & 2,600 & 155 \\
\hline 1,100 & 4,590 & 210 & 4,700 & - & 11,100 & 11,300 & 110 & 1,900 & 154 \\
\hline 1,200 & - & - & 3,200 & - & 4,100 & 5,300 & 100 & 1,750 & - \\
\hline
\end{tabular}

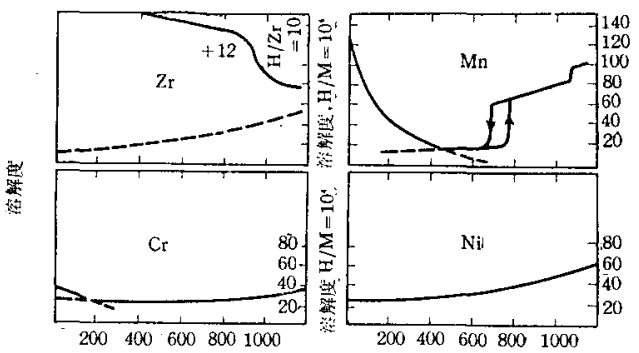

湿嘓 ${ }^{\circ} \mathrm{C}$

図一13 各暞金属に対する水素の溶解度線

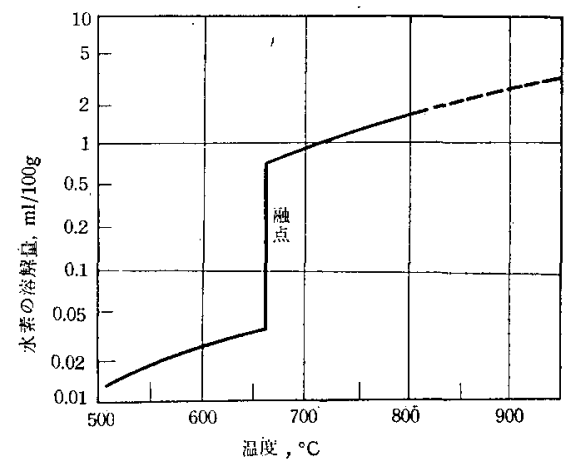

図一14 Al の [H] の溶解度

減少する。しかしながら破線で示されるように1部の水 素は endothermic な固溶をするのであるが，その䭪は 此校的少ないため䒠際には㓋祭されない。ニッケルは endothermic に固溶する典型的な型である. マンガン， クロムはこれらの2つの型が重骨している.すなわち， 低温では exothrmic な固溶を示し, 高温で endothermic な固溶を示すものである。

さてアルミニウムについては, 前述のでとき過程で一 応 endothermicな型によって水菜を固溶するものと考え られている，図一14，15はアルミニウムに対する水素の 溶解度を示すすのである゙,15). しかしながらアルミニウ

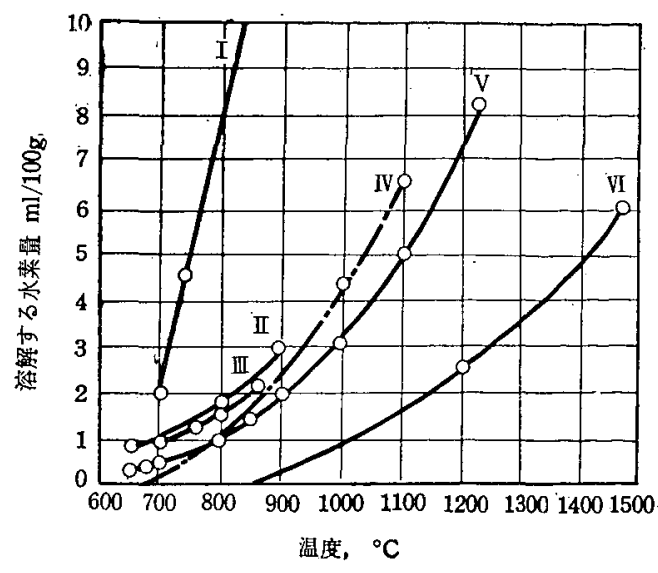

I-Ivaze

IL-Bauklch and Oesterlen III-Ransley and Neufeld IV-Röntgen and Braun $V$-Röntgen and Moller VI-Czochralski

図一15 アルミニウムに対する水㨞の溶解度州線

表一 5 [H]の Al 亿対する溶解度

\begin{tabular}{|c|c|c|c|}
\hline 混庭: ${ }^{\circ} \mathrm{C}$ & $\mathrm{m} / / 100 \mathrm{~g}$ & 西 $\%$ & $\mathrm{H} / \mathrm{Al} \mathrm{lt}$ \\
\hline 850 & 2 & $8.4 \times 10^{-5}$ & $4.8 \times 10^{-5}$ \\
\hline 660 (溶融) & 0.7 & $2.8 \times 10^{-5}$ & $1.6 \times 10^{-5}$ \\
\hline \multirow{2}{*}{ 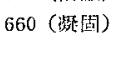 } & 0.04 & $0.17 \times 10^{-5}$ & $0.1 \times 10^{-5}$ \\
\hline & 0.01 & $0.042 \times 10^{-5}$ & $0.024 \times 10^{-5}$ \\
\hline
\end{tabular}

ム中に固溶する $[\mathrm{H}]$ が endothermic の型に属するとと は必ずしも決定的なわけではない，著者らは種々の垁験 から $\mathrm{Al} \cdot \mathrm{H}$ の結合を考慮すべきであると考えている。す なわち，アルミニウム中への $[\mathrm{H}]$ の拡散速度が大きい のに比較して，アルミニウム中からの[H]の脱ガスが きわぬて困難であるととを实験で経験するからである。

$$
\mathrm{Al}+[\mathrm{H}] \rightleftarrows \mathrm{Al} \cdot \mathrm{H}
$$

この反応は右へはきわめて速やが進むが，左へは淮 みにくく，非可逆な反応之考えざるを得ない上うで苛 る. 図一-14kよって明らかなように，Alにおいては， $850^{\circ} \mathrm{C}$ の溶融状態て $2 \mathrm{ml} / 100 \mathrm{~g}$ の水素軍を溶解する が，常温では $0.01 \mathrm{ml} / 100 \mathrm{~g}$ 程度に減少する. と机を原 子比になおする。，表一 5 のごとくなる。

この表でわかるでとく，固溶する平衡 $[\mathrm{H}]$ はきわめ て少なく，他の金属にくらへててもはるか低い值であ る.乙のような微星の平衡 [H] がアルミニウムの機械 的性質その他諸性質に大きな影響を与えることは考えに くい.

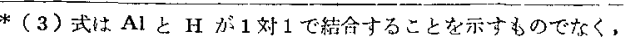

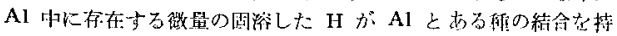

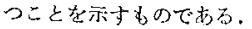




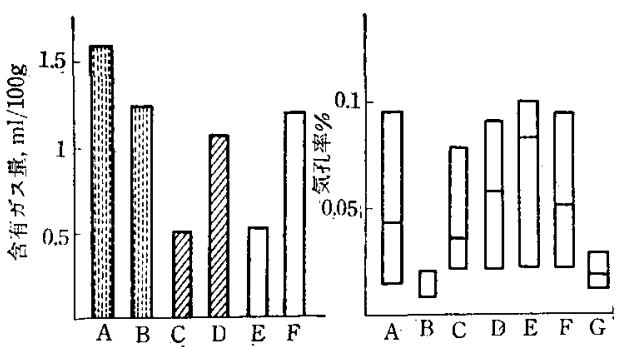

$\mathrm{A}: 850^{\circ} \mathrm{C}$ で $[\mathrm{H}]$ を飽和させ，融点直上より 急冷した試料

B : $850^{\circ} \mathrm{C}$ で [H] を飽和させ，炉内で緅冷し た試料の試料

$\mathrm{C} ： \mathrm{~A}$ 真空中で $750^{\circ} \mathrm{C}$ で高周波炋により再 溶解した試料, 融点直上より急冷

$\mathrm{D} ： \mathrm{~A}$ の試料を真空中で $750^{\circ} \mathrm{C}$ で抵抗炬によ り再溶解した試料, 融点直上上り急冷

$\mathrm{E} ： \mathrm{~A}$ の試料を空気中で $750^{\circ} \mathrm{C}$ で高周波炉に 上り再溶解した試料, 融点直上より急冷

F：Aの試料を空気中で $750^{\circ} \mathrm{C}$ で抵抗炬に上 り再溶解した試料, 融点直上より急冷

$\mathrm{G}: \mathrm{F}$ の試料之同じ再溶解試料, 洷内で綬冷

図一16 99.99\% Al 亿よ万過冷却の実験結果

そこで著者らはアルミニウム溶接部について分析した 水素量から考えて [H] は固体アルミニウム中に過飽和 状態で相当量固溶すると考えている，アルミニウムの凝 固点に打ける急峻な溶解度の咸少はアルミニウム特有の あのであるが，（3）式の上うな非可逆反応と [H] が 小さい原子であるととを考えれば，アルミニウム中に [H]が過飽和状態で相当量存在すると考えることは可能 である．図一16はこのような過飽和状態を検討するため に行なった著者らの実験である ${ }^{16)}$ ，実験化用いた試料は 99.99\%の高純度了ルミニウムであるが $850^{\circ} \mathrm{C}$ ではアル ミニウム中に $[\mathrm{H}]$ は $2 \mathrm{ml} / 100 \mathrm{~g}$ 溶解するが, 念冷し たときほとんどそのまま固溶する，また相当緩冷しても 相当な量が過飽和状態で固溶する。しかしながら，一 方, 気孔は急冷した試料任多く，緩冷した試料们きわ て少ない，ての気孔内のガス压を常王と仮定すれば（実 際には気孔の内压は高いようである)，気孔として析出 した水素ガス量は過飽和固溶量の1/10 1/50 程度しか ない．ま地真空 $\left(10^{-2} \mathrm{mmHg}\right)$ で脱がスしても效果が 少ないという実験結果を得たがてれは真空脱がスという ような物理的な方法ではアルミニウムから $[\mathrm{H}]$ を分離 すること困難なととを示すすのであるままた真空度を $10^{-4} \mathrm{mmHg}$ 程度としても溶融した [H] の脱ガスには きわめて長い時間を必要とすることは経験的に明らかで ある．以上を総合すると $\mathrm{Al} \cdot \mathrm{H}$ の結合を暗示するもの がある。一方，高周波溶解のよう亿外部よりエネルギー を与える方が脱ガス効果があることもこのことを亱づけ
るあのであろう.

図-17は著者らが Al-Mg 合金（NP 5/6）の溶接部 について気孔率之含有ガス量の関係を求めたものであ る17)、この図からわかるごとく, $\mathrm{Al}-\mathrm{Mg}$ 合金で気孔率 0 のとき[H]の含有星は 2 2.5 ml $/ 100 \mathrm{~g}$ であり，純つ ルミ二ウムの場合と同様に過飽和固溶が考えられる. 图 一18はマグネシウム中の水素の溶解度を示すすのである

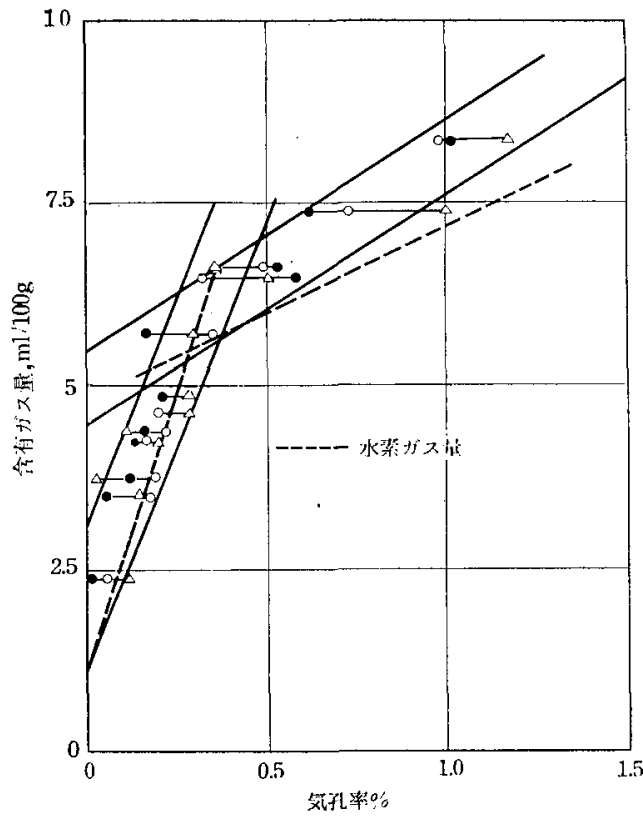

図-17 Al-Mg 合金（NP 5/6）溶接部の気孔 率亡含有ガス量の関係

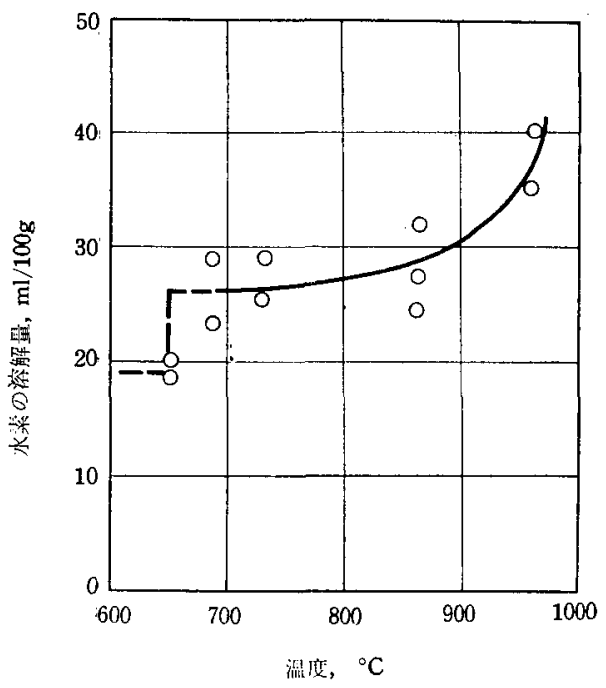

図一18 マグネシウム中の水素の溶解量（Winterhager による) 


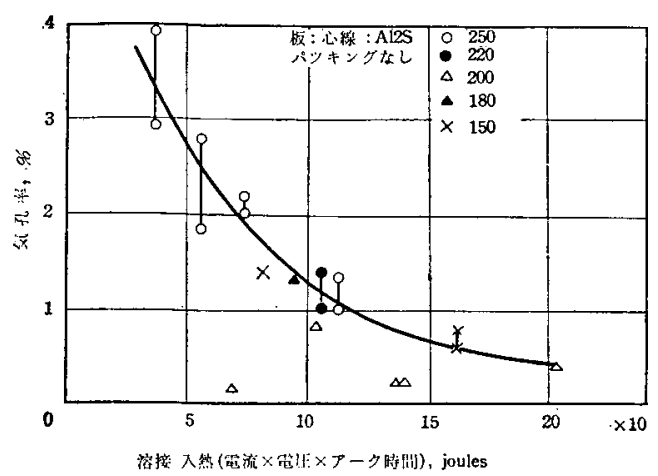

図一19 溶接入熱と気孔率の関係

が,アルミニウムに比べて溶解度ははるかに大きい （A1-Mg 合金ではマグネシウムの含有量に比例して水素 の溶解量が増加するのではなく，合金の水素の含有量に ついては別に考えねばならない).

さて一般にアルミニウムの溶解の場合に比べて, 溶接 の場合には気孔となった水素ガスの影響はきわめて大き いことはいうまでもない，溶接施工に際して，水分の分 解によって生じた水素は溶融池中に拡散して多量の水菜 を溶解するが，溶融池の颣固に際して，アルミニウムに 対する水素の溶解度が激減し, 溶解した水素は析出して 多量の気孔を生ずる. 著者引はてれらの定説に加えて, アルミニウム溶接部の諸性質におよぼす水素の影響を次 の2つに分けることができると考えている.

1）溶接施工時の過冷却によ。 て, 溶解した水素は過飽和状態で凝 固したアルミニウム中に固溶し, 溶 接部のミクロ的な゙諸性質に大きな影 響を与える。

2）凝固時に, 過飽和最以上の溶 解した水菜は析出して気孔となる が, これらの気孔は当然, 溶接部の マクロ的な諸性質に大きな影響を与 える.

\section{これらの考え方を実証するため著} 者らは溶接施工をモデル化して一連の笑験を焦めつつあ る。この実験により現在まで次の結果が得られた ${ }^{18}$.

1）図一19はモデル化溶接実験により求めた溶接入熱 上気孔率の関係であるが溶接入熱が多い上き, 気孔の発 生は少ない,このことは, 図一4において示した著者ら の実際の溶接施工の場合のガス分析の結果上一致する. この結果より, 溶瀜池の冷却速度の影響が気孔の発生に 大きく影響することが考えられ，図一11の冷却速度の影 響とも一一致する。

2) 図一-20は溶接電流が多くなると, 溶融池の温度が

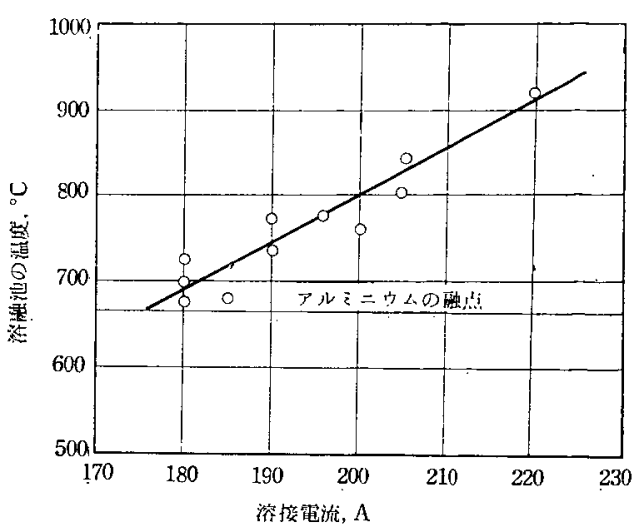

図一20 溶接電流と溶融池の温度の関係

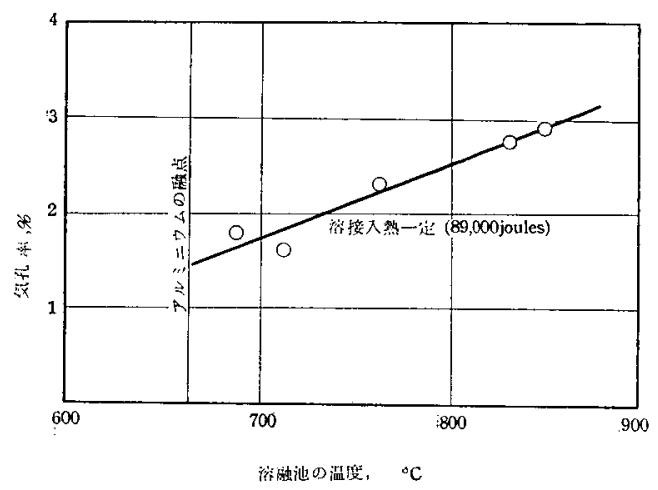

図一21 溶融池の温度上気孔率の関係

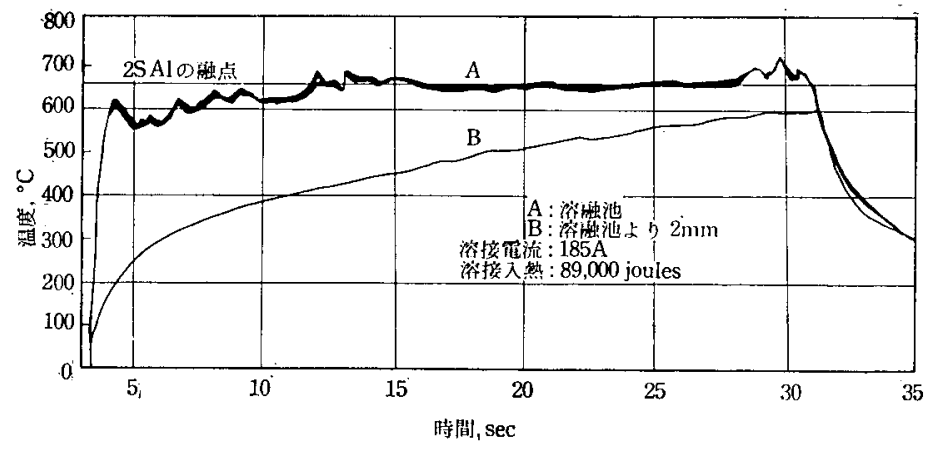

目一22 溶接部の温度の変化

いちじるしく上昇することを示している. こして図一21 は溶接入熱一定の条件で溶融池の温度と気孔率の関係を 求めたものであるが, 溶融池の温度が高くなるとき, 気 孔の発生が多くなるととを示し, 溶融池の温度をすげな いととが溶接施工で必要なことを示している．鈴木氏ら によって得られた図一7の溶接電流と気孔数の関係は著 者らの実験結果を一見反する結果になっているが，鈴木 氏らの結果は実験過程ておいて入熱一定の条件が入って いないため, 溶融池の温度の影響はあらわ机ないで, 入 熱の影響があらわれているもの之考えられる。 


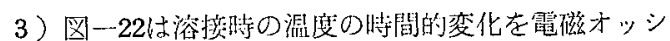
ログラフでとったものである，1）において冷却速度が 気孔の発生に影㗽するととを述べたが，実際は溶融池の 溶解されている時間が大きく影堲し，冷却速度と重胃し て影響を示すとよが考えられる。これについて著者らは さらに䒠験を進めている。

\section{6. 結語}

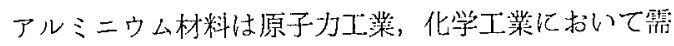
楚を增大している.アルミニウム材料の成形加目に抬い て溶接は欠くことのできないものである．とくに高品貿 の溶接は今後強く要望されることになるう。溶接部の含 有ガスは原子炉で使用される場会，中性子照射により活 性化され，各種の影響があらわれることが若えられる。 また含有水素と残留応打の関係屯今後明らかにされねば ならない。

このようにアルミニウム合雓材料の漫揌に打ける気孔
の間題を解明するためにはいくつかの基礎的研筧を積み 重ねばならないと考えている。

\section{7. 参考文献}

1) Smishells et al : Gases and Metal (1937), Book

2) Smith, D.P. et al : Hydrogen in Metals (1948), Book

3) Smith, D.P. et al: Gases in Metals (1953), Book

4) Sokolskay, L.I. : Gases in Light Metals (1961), Book

5) Koziarski, J, : Weld. J. Vol. 36 (1957) p. 141

6) Collins, F.R. : Weld. J. Vol. 37 (1958) p. 589

7) Daley, D.M. : Weld. J. Vol. 39 (1960) p. $301 \mathrm{~S}$

8) Koziarski, J. : Weld. J. Vol. 32 (1953) p. 970

9）安滕，滕村，生田目：渗接学会落 Vol. 29 (1960) p. 326

10) Westendor R.G. : B. Weld. J. Vol. 8 (1961) p. 310

11）日本溶接協会 AX 委员会：溶按技街 Vol. 8 (1960) No. 10

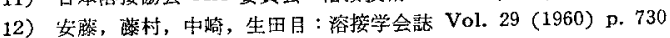

13）鈴木，村瀬：溶接学会婄 Vol. 25 (1956) p. 618

14）日本溶接招会原子力委員会：昭和 32 年度科学技術打原于力平和利

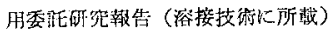

15) Ransley, C.E. et al : J. Inst. Metals Vol. 74 (1948) p. 599

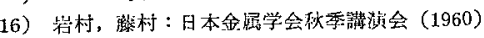

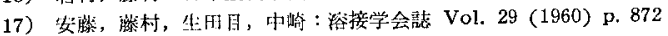

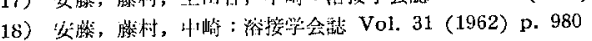

\section{（書 評）}

『最新溶揬ハンドブック增補版』

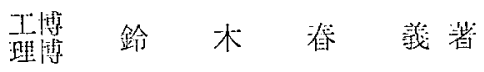

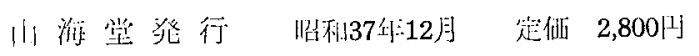

「最新溶接ハンドブック」は斯界の名落として各方酒 飞定評があるが，このたび炭酸がスアーク浴接の画期的 な発展に呼応して，乙の今野の詳細な技汸資料を堌補 し，増補版の刊行をみたととは誠に時宜を得た企てであ

る。本書の堌補版では各種炭酸ガスアーク浴接法の利

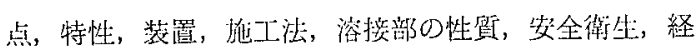

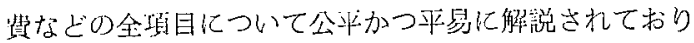
全く胜し分のない内豀である。

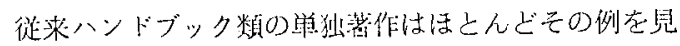
ないもので，よくもこ机まで深接技修の精㳡を明快に整

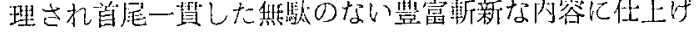
られたものと感䓡している：ての大名著には著者の高遇 な学識，辰格がにじタ出ており，活字を通しながら直接 私どあ在烈切ていねい教示している。本書はあらゆる

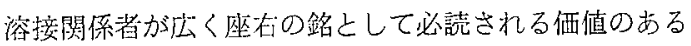

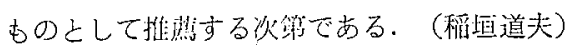

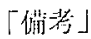

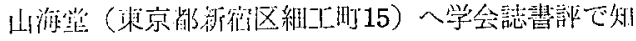

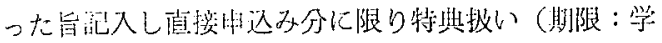
公誌筧载日上り 2 ケ月以队）される。 